\title{
RESULT FORM
}

\section{SPIDIA-RNA - Protocol B - EDTA}

Please, remind that Result Form have to be completed both in the on-line version and in the paper copy.

Attention: Please, fill out the form completely! You won't be able to change parts, selections or answers after sending.

Please insert the internal number referring to your lab (XXX)

1 Status of Blood Samples

11 How is the status of the received blood samples?

Indicate the condition of the blood samples after arrival

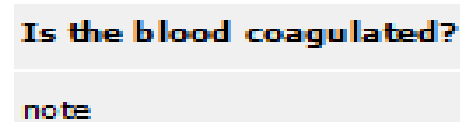

note

Is the blood hemolysed?

note

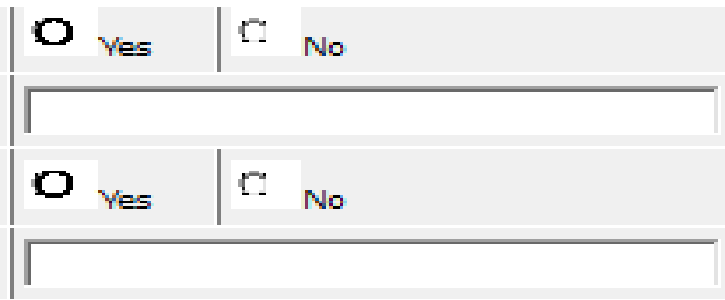

12 What is the temperature of the samples at the arrival?

Indicate the temperature of the blood samples at the arrival

\begin{tabular}{|l|l|l|}
\hline $\begin{array}{l}\text { When you open the package, the samples } \\
\text { temperature is }\end{array}$ & $\mathbf{L}_{\text {cool }}$ & $\mathbf{C}_{\text {RT }}$ \\
\hline note & & \\
\hline
\end{tabular}


2. Storage Time and Temperature of Blood Samples

Indicate the date and time of: blood samples arrival, RNAs extraction and the blood storage temperature between blood samples arrival and RNAs extraction.

\begin{tabular}{|c|c|c|c|c|c|}
\hline & \multicolumn{2}{|c|}{$\begin{array}{l}\text { Date and Time } \\
\text { Samplesarrival }\end{array}$} & \multicolumn{2}{|c|}{$\begin{array}{l}\text { Date and Time } \\
\text { of RNAs Extraction }\end{array}$} & \multirow{2}{*}{$\begin{array}{l}\text { Temperature of } \\
\text { blood storage } \\
\text { between arrival } \\
\text { to RNA } \\
\text { extraction } \\
\qquad\left({ }^{\circ} \mathrm{C}\right)\end{array}$} \\
\hline & (dd/mm/yy) & (hour:min) & (dd/mm/yy) & (hour:min) & \\
\hline Tube C & & & 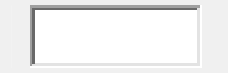 & & \\
\hline Tube D & 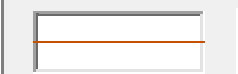 & & $\Gamma$ & : & \\
\hline & \multicolumn{5}{|l|}{ Notes } \\
\hline Tube C & & & & & \\
\hline Tube D & & & & & \\
\hline
\end{tabular}

3. Extraction Method

\begin{tabular}{|l|l|}
\hline RNA extraction Procedure from Blood samples* \\
\hline Producer/Supplier/Hombrew & \\
\hline Catalog Number/Model & \\
\hline \hline
\end{tabular}

\section{NOTES:}

*If you use a manual Protocol, please upload here a file in WORD and in English reporting the protocol you have used for the RNA extraction from the Blood samples.

4. Do you use DNAse treatment?

Do you use DNAse?

$$
\begin{array}{|l|l}
\hline 7 \text { Yes } & 0 \\
\end{array}
$$


5. Storage Time and Temperature of extracted RNAs

Indicate the date and time of the spectrophotometric measurementsand the storage temperature between RNAs extraction and spectrophotometric analysis.

\begin{tabular}{|l|c|c|c|}
\hline & \multicolumn{2}{|l|}{$\begin{array}{l}\text { Date and Time } \\
\text { of RNAs Spectrophotometric Analysis }\end{array}$} & $\begin{array}{l}\text { Temperature of RNA } \\
\text { sorage between } \\
\text { extraction to analysis }\end{array}$ \\
\hline & $(\mathrm{dd} / \mathrm{mm} / \mathrm{yy})$ & (hour:min) & \\
\hline RNA C & $\square$ & $\square$ & \\
\hline RNA D & $\square$ & $\square$ & \\
\hline & Notes & \\
\hline RNA C & & & \\
\hline RNA D & & \\
\hline
\end{tabular}

6. Volumes

Indicate the volume of blood used for RNAsextraction, the volume used the elute/resuspend extracted RNAs, the buffer used to elute/resuspend the RNAs

\begin{tabular}{|l|c|c|l|}
\hline & $\begin{array}{l}\text { Blood extraction } \\
\text { volume }(\mu) \text { ) } \\
\text { (Volume of blood used } \\
\text { for RNA extraction }(\mu))\end{array}$ & $\begin{array}{l}\text { Elution/resuspension } \\
\text { volume }(\mu) \\
\text { (Volume used for RNA } \\
\text { elution/resspension }(\mu))\end{array}$ & $\begin{array}{l}\text { Elution } \\
\text { Buffer Used } \\
\text { (Specify the name of solution } \\
\text { used) }\end{array}$ \\
\hline RNA C & - & & \\
\hline RNA D & $\square$ & & \\
\hline
\end{tabular}

How to fill this table i.e: if you use $200 \mu$ l of blood to perform the RNA extraction and you elute the RNA in $100 \mu$ l of TE buffer:

\begin{tabular}{|l|c|l|l|}
\hline & $\begin{array}{l}\text { Blood extraction } \\
\text { volume } \\
\text { (Volume of blood used } \\
\text { for RNA extraction }(\mu))\end{array}$ & $\begin{array}{l}\text { Eluiton/resupsension volume } \\
(\mu) \\
\left(\begin{array}{l}\text { Volume used for RNA } \\
\text { elution/resuspension }(\mu))\end{array}\right.\end{array}$ & $\begin{array}{l}\text { Elution } \\
\text { Buffer Used } \\
\text { (Specify the name of } \\
\text { solution used) }\end{array}$ \\
\hline RNA C & $\sqrt{200}$ & $\sqrt{100}$ & $\sqrt{T E}$ \\
\hline RNA D & $\sqrt{200}$ & $\sqrt{100}$ & $\sqrt{T E}$ \\
\hline
\end{tabular}


7. Spectrophotometric Analysis

7.1Spectrophotometer

\begin{tabular}{|l|c|c|}
\hline & Producer/Supplier/Hombrew & Catalog Number/Model \\
\hline Spectrophotometer & & \\
\hline
\end{tabular}

\subsection{Spectrophotometric Data}

Please record the spectrophotometric data as follows by entering values with at least 3 decimal places. Insert the absorbance value you have obtained by measuring your RNA sample and in the case you measure a diluted RNA, the dilution factor you perform for analysis.

NOTE: Use "dot" as separator

\begin{tabular}{|l|c|c|c|c|}
\hline & A260 & A280 & A320* & Dilution factor** \\
\hline RNA C & $\square$ & $\square$ & $\square$ & $\square$ \\
\hline RNA D & $\square$ & $\square$ & $\square$ & $\square$ \\
\hline
\end{tabular}

*NOTE: If your Spectrophotometer is not equipped to read at $320 \mathrm{~nm}$ put the value NA for A320

**lf you don't dilute the sample insert " 1 " as dilution factor

How to fill this table Example of spectrophotometric resultsif you evaluate $2 \mu$ l of RNA sample diluted in $100 \mu$ of buffer:

\begin{tabular}{|l|c|c|c|c|}
\hline & A260 & A280 & A320* & Dilution factor \\
\hline RNA C & $\sqrt{1.914}$ & $\sqrt{0.855}$ & $\sqrt{0.010}$ & $\square$ \\
\hline
\end{tabular}




\subsection{Please record RNA quantity $(\mathrm{C})$ and purity $(\mathrm{R})$ in the following table}

Please note that in this Table quantity must be reported as concentration $\mathrm{ng} / \mu \mathrm{l}(\mathrm{C}=260 \mathrm{~nm} \times 40 \mathrm{x}$ dilution factor or $C=260 \mathrm{~nm}-320 \mathrm{~nm}) \times 40 \times$ dilution factor) and purity by evaluating the ratio of absorbance value, $R=260 \mathrm{~nm} / 280 \mathrm{~nm}$ or $R=(260 \mathrm{~nm}-320 \mathrm{~nm}) /(280 \mathrm{~nm}-320 \mathrm{~nm})$. Please record the data by entering values with at least 3 decimal places.

NOTE: Use "dot" as decimal separator

\begin{tabular}{|l|c|c|c|}
\hline & RNA quantity (C) $(\mathrm{ng} / \mathrm{\mu})$ & RNA purity (R) & Notes \\
\hline RNA C & $\square$ & & \\
\hline RNA D & $\square$ & $\square$ & $\square$ \\
\hline
\end{tabular}

8. Shipping Time and Storage Temperature of RNAs

Record the date and the time you ship the samples to SPIDIA UNFI laboratory and the storage temperature of RNAs before to send them.

\begin{tabular}{|l|c|}
\hline & Temperature of RNA storage before shipment $\left({ }^{\circ} \mathrm{C}\right)$ \\
\hline RNA C & \\
\hline RNA D & \\
\hline
\end{tabular}

Date and Time of pick up delivery service at your lab

\begin{tabular}{|c|c|}
\hline (dd/mm/yy) & (hour:min) \\
\hline$\square$ & $\square: \square$ \\
\hline
\end{tabular}

\section{Keep this completed Result Form for your record}

Please check your data carefully - you will not be able to edit them later 